\title{
Electrochemical Behavior Zn(II) at Carbon Steel Electrode in Deep Eutectic Solvents Based on Choline Chloride
}

\author{
Evelin Gutiérrez ${ }^{1}$, José A. Rodriguez $^{1, *}$, Julián Cruz-Borbolla $^{1}$, Yolanda Castrillejo ${ }^{2}$, Enrique Barrado ${ }^{2}$ \\ ${ }^{1}$ Área Académica de Química, Universidad Autónoma del Estado de Hidalgo, Unidad Universitaria, \\ km 4.5 Carretera Pachuca-Tulancingo, C.P. 42184 Pachuca-Hidalgo, Mexico. \\ ${ }^{2}$ Dpto. de Química Analítica, Facultad de Ciencias, Universidad de Valladolid, Paseo de Belén 7 , \\ 47011, Valladolid, Spain. \\ *E-mail: josear@uaeh.edu.mx
}

doi: $10.20964 / 2017.10 .01$

Received: 26 May 2017 / Accepted: 19 July 2017 / Published: 12 September 2017

Deep eutectic solvents prepared by mixture of choline chloride with urea, thiourea and ethylene glycol (1:2 molar ratio) were used to study the electrochemical behavior $\mathrm{Zn}(\mathrm{II})$ at carbon steel 1018 electrode. $\mathrm{Zn}$ deposits were immersed in a corrosive media $(\mathrm{NaCl} 3 \% \mathrm{wt})$. Composition of the solvent employed causes a difference in electrodeposition and corrosion behaviors, being diffusion coefficient value a critical parameter associated to these processes.

Keywords: carbon steel; deep eutectic solvent; urea; thiourea; ethylene glycol.

\section{$\underline{\text { FULL TEXT }}$}

(C) 2017 The Authors. Published by ESG (www.electrochemsci.org). This article is an open access article distributed under the terms and conditions of the Creative Commons Attribution license (http://creativecommons.org/licenses/by/4.0/). 